\title{
Evaluation of neomycin analogues for HIV-1 RRE RNA recognition identifies enhanced activity simplified neamine analogues
}

DOI:

10.1016/j.bmcl.2018.11.004

\section{Document Version}

Accepted author manuscript

Link to publication record in Manchester Research Explorer

Citation for published version (APA):

Simon, B., Walmsley, C., Jackson, V. J., Garvey, E. P., Slater, M. J., Berrisford, D. J., \& Gardiner, J. M. (2018). Evaluation of neomycin analogues for HIV-1 RRE RNA recognition identifies enhanced activity simplified neamine analogues. Bioorganic \& medicinal chemistry letters. https://doi.org/10.1016/j.bmcl.2018.11.004

\section{Published in:}

Bioorganic \& medicinal chemistry letters

\section{Citing this paper}

Please note that where the full-text provided on Manchester Research Explorer is the Author Accepted Manuscript or Proof version this may differ from the final Published version. If citing, it is advised that you check and use the publisher's definitive version.

\section{General rights}

Copyright and moral rights for the publications made accessible in the Research Explorer are retained by the authors and/or other copyright owners and it is a condition of accessing publications that users recognise and abide by the legal requirements associated with these rights.

\section{Takedown policy}

If you believe that this document breaches copyright please refer to the University of Manchester's Takedown Procedures [http://man.ac.uk/04Y6Bo] or contact uml.scholarlycommunications@manchester.ac.uk providing relevant details, so we can investigate your claim.

\section{OPEN ACCESS}




\section{Graphical Abstract}

To create your abstract, type over the instructions in the template box below.

Fonts or abstract dimensions should not be changed or altered.

Evaluation of Neomycin Analogues for HIV-1 RRE

RNA Recognition Identifies Enhanced Activity

Simplified Neamine Analogues

Binto Simon, Claire Walmsley, Victoria J. Jackson, Edward P. Garvey, Martin J. Slater, David J. Berrisford and John. M. Gardiner ${ }^{*}$

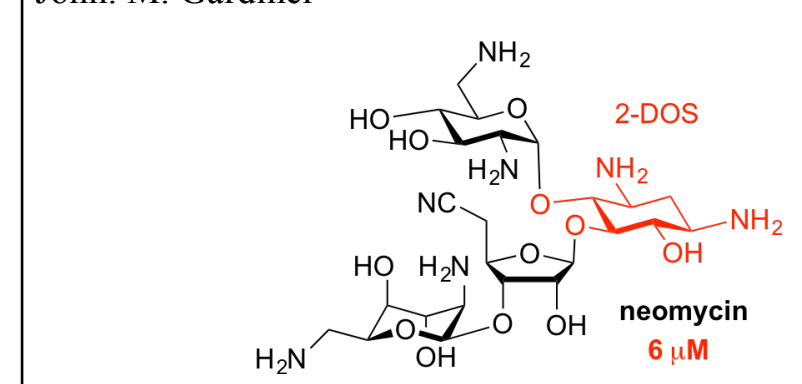

Leave this area blank for abstract info.

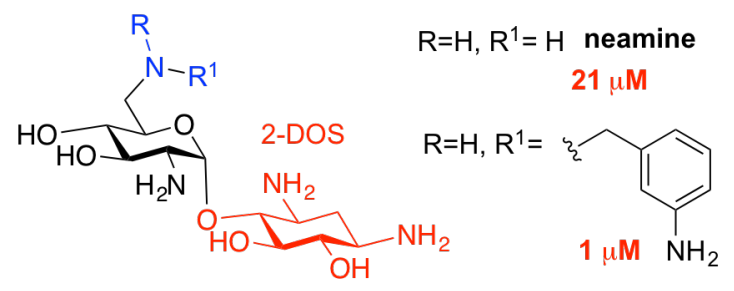

13 semi-synthetic neamine derivatives 


\title{
Bioorganic \& Medicinal Chemistry Letters \\ journal homepage: www.elsevier.com
}

\section{Evaluation of Neomycin Analogues for HIV-1 RRE RNA Recognition Identifies Enhanced Activity Simplified Neamine Analogues}

\author{
Binto Simon, ${ }^{a}$ Claire Walmsley, ${ }^{\mathrm{a}, \#}$ Victoria J. Jackson, ${ }^{\mathrm{a}}$ Edward P. Garvey, ${ }^{\mathrm{c}, \S}$ Martin J. Slater, ${ }^{\mathrm{b}}$ David J. \\ Berrisford $^{\mathrm{a}}$ and John. M. Gardiner*,a \\ ${ }^{a}$ Manchester Institute of Biotechnology and School of Chemistry, The University of Manchester, Manchester M1 7DN, UK \\ ${ }^{b}$ Medicines Research Centre, GlaxoWellcome, Gunnels Wood Road, Stevenage, SG1 2NY, UK
}

\section{ARTICLE INFO}

Article history:

Received

Revised

Accepted

Available online

Keywords:

neomycin

neamine

RNA RRE

HIV-1

Aminoglycosides

\section{ABSTRACT}

Synthetic neamine mimetics have been evaluated for binding to the HIV-1 Rev response element. These The 6-amino modified neamine derivatives, obtained from reductive amination of neamine, led to identification of new 6-amino modified neamine-type ligands with HIV-1 RRE binding affinity up to $20 \mathrm{x}$ that of neamine and up to $6 \mathrm{x}$ that of the more complex neomycin itself. This provides a noteworthy structure-activity increase and a useful lead to simplified, chemically accessible mimetics.

2009 Elsevier Ltd. All rights reserved.
Selective recognition of RNAs of therapeutic interest is a challenging problem. ${ }^{1,2}$ It is formally possible to use an antisense approach as it has the obvious ability to target structural elements within complex RNAs. However, when compared to the success in targeting proteins, successes of small molecules that bind RNAs by structure selective recognition remain limited. Literature examples of this approach include interaction of aminoglycosides with a number of therapeutically relevant RNAs $^{3-6}$. Moreover, there are even fewer examples of molecules that inhibit an RNA-protein interaction in vitro and which also display biological activity in a cellular assay. One of the most notable examples of this type of structure-selective inhibition is the interaction of neomycin B (Fig. 1) with HIV-1 REV response element. ${ }^{7,8}$ However, the degree of selectivity ${ }^{9}$ and potency in cellular assays remain far short of levels required for clinical efficacy, and ways have to be found to minimize the problems of resistance ${ }^{10-12}$ and toxicity. Thus, there is a need to develop our understanding of the structural basis for the recognition process, increase the pool of selective RNA binding ligands ${ }^{13,14}$ and optimize the recognition of therapeutic targets. Modifications have been made to various parts of the neomycin B structure, including the incorporation of additional heteroaromatic functional groups ${ }^{15}$ and dimerizations. ${ }^{16}$

The two-ring neamine core, 2 (Fig. 1) of neomycin is closely related to a key component of a wide range of aminoglycoside antibiotics, which differ in positioning of other sugar attachments. A number of aminoglycosides have modifications ${ }^{17}$ at the 6'-amino of the glucosamine unit (e.g. gentamicins), while some are $\mathrm{GlcN}$ variations with ring amines (e.g kanamycins, tobramycins) or have modifications in the 2-deoxystreptamine (2-DOS) ring eg are 4-amino derivatives (e.g. isepamcin, amikacin). Interest in aminoglycoside antibiotics, their mechanisms of action and development of resistance is currently intense.

Synthesis and design of modified aminoglycoside analogues have been a high profile venture for the last few years, encompassing chemical synthesis and semi-synthesis through to bioengineered approaches. ${ }^{18}$ Many of these have approached modifications of the $2-\mathrm{DOS}^{19-21}$ region of a number of these with 6 '-amino modifications evident in the gentamicins and also in the (4',5'-unsaturated) plazomicin.

Neamine 2 retains some weak binding affinity with the RRE and earlier studies by Wong et al. focused ${ }^{22}$ on derivatisation of the $5-\mathrm{OH}$ of 2 .

Our approach $^{23}$ was to explore the potential for simplifying the neomycin B (1) structure by generating neamine-like analogues through semi-synthesis from neamine aiming to identify structure-activity information for the design of simplified aminoglycosides with pharmaceutical potential. This approach was targeted at systems of types 3 (Fig. 1).

Compounds of type $\mathbf{3}$ may be expected to bind to the HIV-1 Rev Responsive Element (RRE) based on retention of the 2-DOS unit, with the possibility of including additional binding interactions via the $6^{\prime} \mathrm{N}$ modifications. 

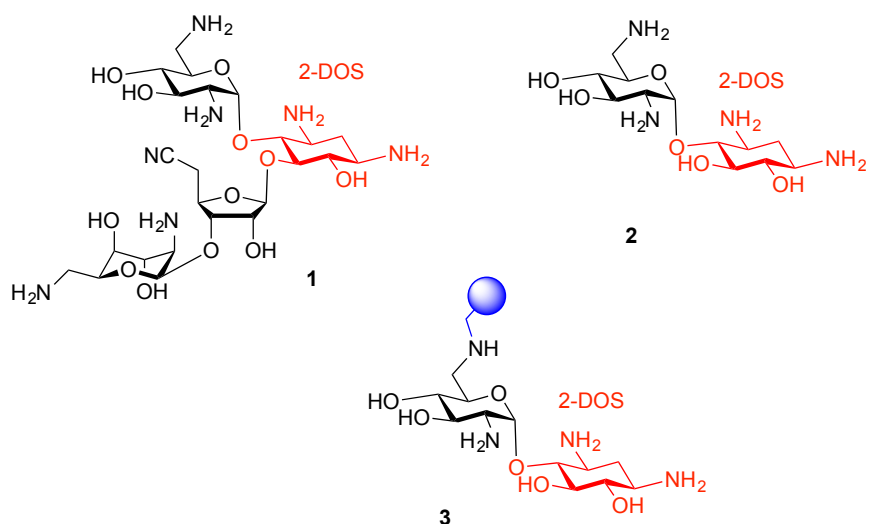

Fig 1. Structures of neomycin, neamine and $N$-alkylated neamine mimetic targets. ${ }^{23}(\mathrm{~N}$-alkyl structures in Table 1$)$.

Wong has proposed interactions of aminoglycoside analogues through triplex-like H-bonding to base pairs. ${ }^{24}$ Our proposed ligand targets may also have hydrogen bonding recognition and/or pi-stacking involving the additional aromatic ring within the internal RNA loop. Such structures could also interact through interaction with RNA backbone phosphates. This rational was based on our own modeling of $6-\mathrm{N}$ modified neamines of type 3 .

(a)

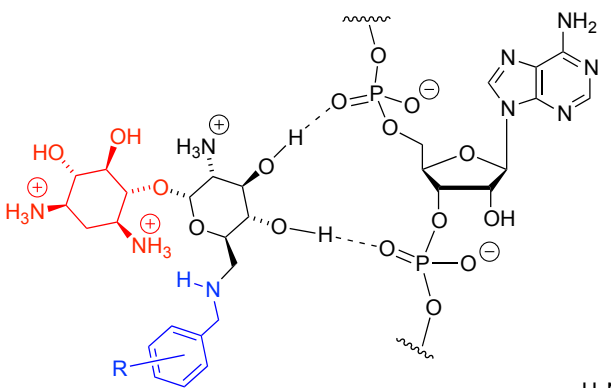

(b)

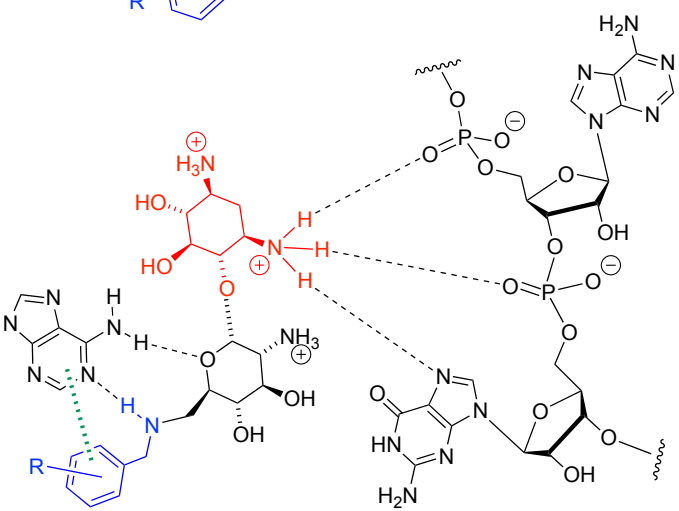

Fig 2. (a) Proposed RNA phosphates interactions with neamine mimetics ring A; (b) Proposed RNA phosphates interactions with neamine mimetics 2 DOS ammonium and adenine interactions with 6-amino modified ring A through $\mathrm{H}$ binding and potential $\boldsymbol{\pi}$-interactions.

Here, we report a study of derivatives prepared by reductive amination of the 6'-amino group of $\mathbf{2}$. We report that a simplification of the neomycin structure to a 6'-amino alkylated fragment approach has led to the identification of a structure with enhanced inhibition of the RRE-rev interaction over the parent neomycin.

We previously reported ${ }^{23}$ the synthesis of neamine derivatives of type $\mathbf{3}$ bearing modified aryl-containing groups on the primary amine, using the alternative approach of reductive amination of the substrate amine with derivatizing aldehydes (the reverse of the model compounds above). Here we report that biological screening of these analogues (Table 1) targeting a biotinylated HIV-1 rev protein and tritiated RRE RNA ${ }^{25}$ using scintillation proximity assay, which provides structure-activity information clearly defining the type of amino modification required for retaining, and indeed increasing binding affinity.

Alkyl substituents have variable effects, but whilst the cyclohexylmethyl derivative $\mathbf{3 b}$ is inactive, the simple ethyl derivative 3a showing affinity comparable to that of the underivatized neamine. Similarly, the dimethylallyl and cinnamyl derivatives (3c and 3d) produced very different data with $\mathbf{3 d}$ showing moderate affinity. $N, N$ '-Dialkylation results in abolition of the binding interaction, e.g. entry 7 (3e). A number of $N$ benzylic derivatives were evaluated. The parent benzyl (3f) and its 2-chloro substituted analogue (3g) show modest but similar affinity. A number of analogues with of 1-3 aromatic substitutions showed enhanced efficacy by 2 to 3 -fold compared to the unsubstituted phenyl of the 2-Cl derivative. Specifically, 2hydroxyl (3h), 2-hydroxyl-ethoxy (3i), p-nitro (3k), 4-hydoxy-3methoxy and 4-hydroxy-3,5-tbutyl all displayed similar inhibitory activities $(17-31 \mu \mathrm{M})$ to neamine itself (Entry 2 ).

Table $1^{\text {a }}$ SAR of 6-amino modified synthetic neamine mimetics $^{23} \quad \mathrm{R}^{1}=\mathrm{H}$ except for $\mathbf{3 e}$

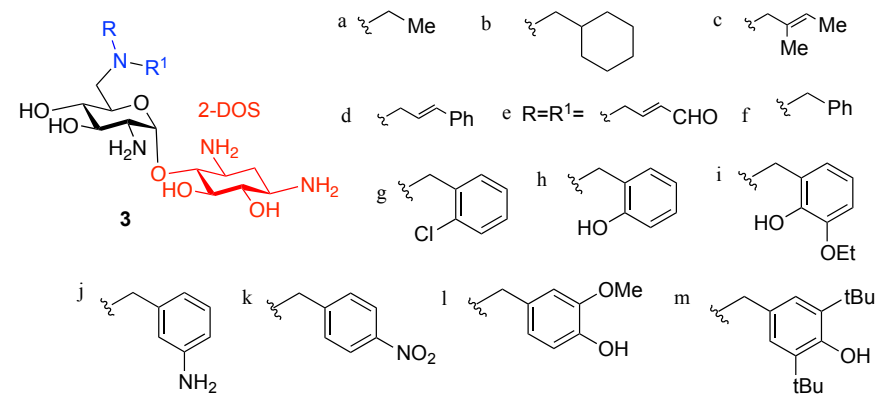

Entry Compound $\quad \mathrm{IC}_{50, \mu M}$

Neomycin, $\mathbf{1}^{b}$

6

Neamine, $\mathbf{2}^{b}$

$\mathrm{R}=\mathrm{R}^{1}=\mathrm{H}$

21

3

5

6

7

8

9

10

11

12

13

14

15

3a

3b $>100$

3c $>100$

3d 32

3e $>100$

3f 63

39

$3 \mathbf{h} 25$

$3 \mathbf{i} 31$

3j 1

$3 \mathbf{3}-25$

$31 \quad 19$

$3 \mathbf{m}$

${ }^{a}$ Scintillation proximity assay using biotinylated HIV-1 rev protein and tritiated RRE RNA. ${ }^{25}{ }^{b}$ Used as control with values consistent with previously reported..$^{25}$

These date do confirm that $6-N$ modification of neamine provides a range of systems comparable to neamine, and that 
alkyl or alkenyl systems (3c and $\mathbf{3 e}$ ) are poor but an additional aryl (3d) recovers much of the affinity. The analysis from a structure and electronic effects viewpoint is less clear with regard to the hypothesis of $\pi$-interactions alone, as these span a range of very electron rich to poor systems, where ring electronics appear to have minor impact. The large jump in affinity is through introduction of an additional amine on an aromatic and thereby we propose that not only hydrophobic or $\pi$-effects may be involved but the extension adding an amine/ammonium may be recruiting additional electrostatic or H-binding interactions beyond the native neomycin binding. This single change leads to a 20 -fold enhancement over neamine and the 6-fold enhancement over the larger neomycin parent. This provides a valuable observation for future design of modify neamines by skeleton extension.

However, compound $\mathbf{3 j}$ derived from 3-aminobenzaldehyde (3j) proved to be ca. six-fold more potent than neomycin itself, and 20 -fold more potent than the parent neamine.

These data demonstrate that it is possible to simplify the neomycin structure, modifying the 2-ring substructure of neamine with a relatively lipophilic functional group, to provide a number of derivatives which inhibitory efficacy similar to that of neamine. Critically, though, is the identification of $\mathbf{3 j}$ as a valuable new lead which in these assays significantly exceeds the activity of the parent neomycin.

In conclusion, a range of reductive amination-derived neamine derivatives containing the 2-DOS ring were evaluated for HIV-1 RRE inhibition. This has led to the identification of a lead compound with HIV-1 RRE affinity at $1 \mu \mathrm{M}$ and thus approximately 6-fold better than parent antibiotic neomycin and $20 \mathrm{x}$ that of neamine. This strategy of 6 -amino modification provides a valuable approach for further development of enhanced neomycin mimetics.

\section{Acknowledgments}

The first author (BS) would like to thank School of Chemistry, University of Manchester and Professional and Career. Development Loan for the financial support. We are grateful to the EPSRC and GlaxoWellcome for a studentship to CLW.

\section{References and notes}

\#Current address: Vernalis $(\mathrm{R}+\mathrm{D})$ Ltd, Granta Park, Great Abington, Cambridge CB6 6GB, United Kingdom.

§Current address: Vice President, Biology, Viamet Pharmaceuticals, Inc., 4505 Emperor Blvd, Suite 300, Durham, NC 27703, United States.
1. Dibrov, S. M.; Parsons, J.; Carnevali, M.; Zhou, S.; Rynearson, K. D.; Ding, K.; Sega, E. G.; Brunn, N. D.; Boerneke; M. A.; Castaldi M. P.; Hermann, T. J. Med Chem. 2014, 57, 1694-1707.

2 Gallego J.; Varani, G. Acc. Chem. Res. 2001, 34, 836-843.

3 Vo, D. D.; Staedel, C.; Zehnacker, L.; Benhida, R.; Darfeuille F.; Duca, M. ACS Chem. Biol. 2014, 9, 711-721.

4 Sczepanski J. T.; Joyce, G. F. J. Am. Chem. Soc. 2015, 137, 16032-16037.

5 Das, I.; Désiré, J.; Manvar, D.; Baussanne, I.; Pandey V. N.; Décout, J. L. J .Med Chem. 2012, 55, 6021-6032.

6 Jiang, L.; Watkins, D.; Jin, Y.; Gong, C.; King, A.; Washington, A. Z.; Green K. D.; Garneau-Tsodikova, S.; Oyelere, A. K.; Arya, D. P. ACS Chem. Biol. 2015, 10, 1278-1289.

7 Zapp, M. L.; Stern S.; Green, M. R. Cell 1993, 74, 969-978.

8 Jayaraman, B.; Mavor, D.; Gross, J. D.; Frankel, A. D. Biochemistry 2015, 54, 6545-6554.

9 Blakeley B. D.; McNaughton, B. R. ACS Chem. Biol. 2014, 9, 1320-1329

10 Garneoau-Tsodikova S.; Labby, K. J. Med. Chem. Commun. 2016, 7, 11-27.

11 Mingeot-Leclerq M.-P.; Decout, J.-L. Med. Chem. Commun. 2016, 7, 586-611.

12 Bacot-Davis, V. R.; Bassenden A. V.; Berghuis. A. M. Med. Chem. Commun. 2016, 7, 103-113.

13 Li, K.; Davis, T. M.; Bailly, C.; Kumar, A.; Boykin D.W.; Wilson, W.D. Biochemistry 2001, 40, 1150-1158.

14 Xiao, G.; Kumar, A.; Li, K.; Rigl, C. T.; Bajic, M.; Davis, T. M.; Boykin D. W.; Wilson, W. D. Bioorg. Med. Chem. 2001, 9, 10971113.

15 Luedtke, N. W.; Baker, T. J.; Goodman M.; Tor, Y. J. Am. Chem. Soc. 2000, 122, 12035-12036.

16 Wang H.; Tor, Y. Angew. Chem. Int. Ed. 1998, 37, 109-111.

17 Artigas G.; Marchán, V. J. Org. Chem. 2015, 80, 2115-2164.

18 Winn, M.; Fyans, J.; Zhuo Y.; Micklefield, J. Natural Product Reports 2016, 33, 317-47.

19 Ding, Y. L.; Hofstadler, S. A.; Swayze, E. E.; Risen L.; Griffey, R. H. Angew. Chem. Int. Ed. 2003, 42, 3409-3412.

20 Vourloumis, D.; Winters, G. C.; Takahashi, M.; Simonsen, K. B.; Ayida, B. K.; Shandrick, S.; Zhao Q.; Hermann, T. Chem. Bio. Chem. 2003, 4, 879-885.

21 Greenberg, W. A.; Priestley, E. S.; Sears, P. S.; Alper, P. B.; Rosenbohm, C.; Hendrix, M.; Hung S. C.; Wong, C.-H. J. Am. Chem. Soc. 1999, 121, 6527-6541.

22 Park, W. K. C.; Auer, M.; Jaksche, H.; Wong, C.-H. J. Am. Chem. Soc. 1996, 118, 10150-10155.

23 Nunns, C. L.; Spence, L. A.; Slater M. J.; Berrisford, D. J. Tetrahedron Lett. 1999, 40, 9341-9345.

24 Hendrix, M.; Priestley, E. S.; Joyce G. F.; Wong, C.-H. J. Am. Chem. Soc. 1997, 119, 3641.

25 Chapman, R. L.; Stanley, T. B.; Hazen R.; Garvey, E. P. Antiviral Res. 2002, 54, 149-162. 